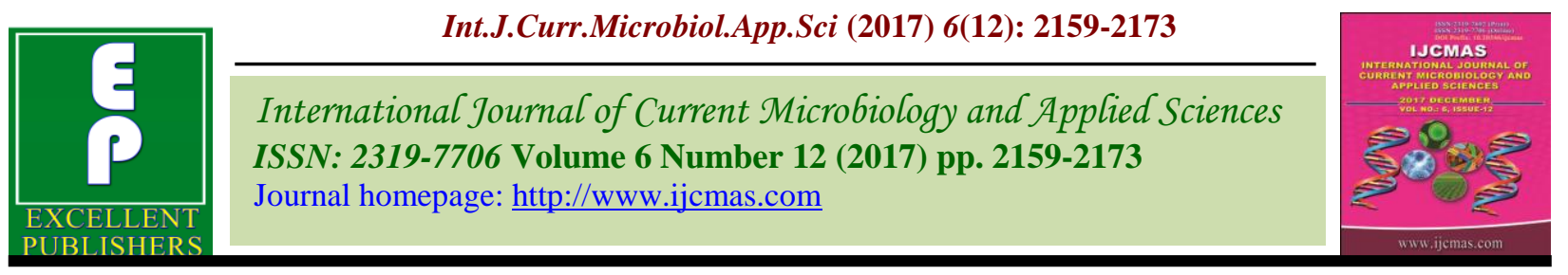

Review Article

https://doi.org/10.20546/ijcmas.2017.612.248

\title{
Past and Present Overview of "Orf"
}

\author{
Anita Dalal ${ }^{1}$, Vinay Kumar ${ }^{2}$, Deepika Chaudhary ${ }^{2}$, Nitish Bansal', \\ Aman Kumar', Naresh Kakker ${ }^{1}$ and Sushila Maan ${ }^{2 *}$ \\ ${ }^{1}$ Department of Veterinary Microbiology, ${ }^{2}$ Department of Animal Biotechnology, College of \\ Veterinary Sciences, Lala Lajpat Rai University of Veterinary and Animal Sciences, \\ Hisar, 125 004, Haryana, India \\ *Corresponding author
}

A B S T R A C T

\begin{tabular}{|c|c|}
\hline & \\
\hline $\begin{array}{l}\text { Orf, Parapoxvirus, } \\
\text { Virulence factors, } \\
\text { Immune factors, } \\
\text { Diagnostics. }\end{array}$ & $\begin{array}{l}\text { Orf, having multiple synonyms as contagious pustular dermatitis or } \\
\text { contagious ecthyma possesses zoonotic potential, is viral skin disease } \\
\text { affecting health of ruminants mainly. It is due to the infection of Orf virus } \\
\text { belonging to Parapoxvirus genus of family Poxviridae, with characteristic }\end{array}$ \\
\hline Article Info & barn of wool like morphology of capsid. In the present article, all the details \\
\hline $\begin{array}{l}\text { Accepted: } \\
17 \text { October } 2017 \\
\text { Available Online: } \\
10 \text { December } 2017\end{array}$ & $\begin{array}{l}\text { from history to patho-physiology of virus (major virulence factors) and host } \\
\text { (immune factors) along with up to date diagnostics, epidemiology and } \\
\text { control measures have been reviewed. }\end{array}$ \\
\hline
\end{tabular}

\section{Introduction}

Sheep and goats are a great investment of poor farmers and so, are called as poor man's cow. The health and production of these small animals is markedly affected by various bacterial and viral pathogens, including Contagious Ecthyma (CE) that hovers all over the world (de la Concha-Bermejillo, 1995, Mondal et al., 2006). The CE is an acute, contagious, debilitating and epithelio-trophic viral disease of small ruminants, other domesticated and wild ruminants. The disease is known by multiple synonyms as sore mouth, contagious pustular dermatitis (CPD), scabby mouth or infectious labial dermatitis (Thomas et al., 2003). The etiological agent is Orf virus and the infection is characterized by nonsystemic eruptive skin lesions (de la Concha-Bermejillo, 1995, Mondal et al., 2006).Walley (1890) first described the disease in sheep and referred it as Contagious Dermatitis or Orf.

Hoare (1913) first used the term Contagious Pustular Dermatitis and Glover (1928) used the same terminology to describe the disease which had been defined that time as a distinct clinical entity in Great Britain.

The term Contagious Ecthyma was first used by Mossu. Peterkin (1937) described the zoonotic importance of the disease. Since then the disease in man has been referred to as Orf, 
and the virus named Orf virus (Robinson and Balassu, 1981).

\section{Clinical signs}

The disease is clinically manifested via proliferative cauliflower like lesions which may later be ulcerated on the mouth (the commissures of the lips and along the gum margins surrounding the incisor teeth), muzzle and crustated nodular lesions on dorsum of tongue. Hoof/horn junction or hair less/wool less parts of body may also get affected (Kumar et al., 2016). These lesions usually get rid off spontaneously in 1-2 months (McKeever et al., 1988). Primary Orf lesions become most severe with a clinical progression from erythematous macule, papule, vesicle, pustule and finally to scab formation in 4-6 weeks period. The Orf is more severe in goats than in sheep and moreover, the young animals are at higher risk.

In a large flock, the initial papule and vesicle stages rarely draw attention. The subsequent scabs progressing to large proliferative wartlike structures that bleed profusely following trauma at the base, are more commonly visible. Severe facial and oral lesions in lambs may interfere with suckling. The debilitating disease can become lethal if such lambs and kids succumb to secondary bacterial or fungal infections (Haig and McInnes, 2002). Lesions on the udder and teats may result in the desertion of off-springs and foot lesions may cause transient lameness. Vaccinated and previously infected animals may get reinfected by the same virus as there is no development of solid immunity. In such cases although lesions progress through the same clinical stages but they are generally smaller, non-proliferative and resolve somewhat rapidly i.e., 2-3 weeks. The morbidity of the disease may reach up to $100 \%$ but simultaneously mortality do occur if superseded by secondary bacterial infections, and may reach up to $15 \%$ (Gumbrell and McGregor, 1997).

In humans Orf usually manifests after a 3-7 day incubation period on the hands (Khaled, 2009) but unusual locations have also been described including the nose, scalp, axilla, buttocks, and genitals (Key et al., 2007, Frandsen, 2011). Most of the infections in humans are localized and self-limiting. However, in immunosuppressive individuals large poorly healing lesions are seen including highly vascularized tumour, cauliflower-like mass of granuloma and painful lesions on skin (Rørdam et al., 2013). Further, human-to-human transmission has not been reported (CDC, 2012; Caravaglio et al., 2017).

\section{The virus}

Orf virus is the type species of the genus Parapoxvirus of the subfamily Chordopoxvirinae of the family Poxviridae (Matthews, 1982). The other members of the genus include Bovine Papular Stomatitis virus (BPSV), Parapoxvirus of red deer in New Zealand (PVNZ) and Pseudocowpox virus (PCPV). Furthermore, three tentative species that have been included in the genus are Auzdyk Disease Virus, Chamois Contagious Ecthyma Virus and Seal Pox Virus (Buchen Osmond, 2003). The Parapoxviruses are antigenically and genetically related and have similar morphology, genomic organization and virulence mechanism (Fleming et al., 1993).

The Parapoxviruses are ovoid in shape, have criss-cross patterned tubule-like structure on surface of virus particle giving it a basketweave appearance (Mercer, 2006). The virions are cocoon shaped of about $260 \mathrm{~nm}$ long and $160 \mathrm{~nm}$ wide and covered with long thread like surface tubules resembling a ball 
of yarn. In resemblance with other poxviruses, Orf viruses replicate in the cytoplasm of host cells and encode their own machinery of enzymes for DNA transcription and replication.

Electron microscopy of the Orf virus particles stained with phosphotungstate reveals two interchangeable forms. The type 1 or $M$ (Mulberry) form showing the characteristic "ball of wool" appearance due to crisscrossing of the tubular protein threads on the surface. The type 2 or $\mathrm{C}$ (Clear) form is phosphotungstate permeable. By analogy with vaccinia 29 virus, the type 2 forms are damaged type 1 virions, which allow penetration of stain. Type 1 can be converted into type 2 forms by treating the particles with organic solvents or alkaline ( $\mathrm{pH} \mathrm{8-11)} \mathrm{buffers}$ (Robinson and Balassu, 1981).

\section{Genome organization}

The Orf virus genome is the smallest of all other Poxviridae family members, is about $140 \mathrm{kbp}$ linear double-stranded DNA with $64 \% \mathrm{G}+\mathrm{C}$ content, closed hairpin loop at termini and genes located on both strands in bidirectional orientation (Zhang et al., 2014). At each pole $3 \mathrm{kbp}$ DNA folds to form an inverted terminal repeat (ITR). The Orf virus genome contains 132 putative genes including 89 highly conserved genes and some variable genes (Delhon et al., 2004; Mercer et al., 2006).The central region (CORE) carries conserved genes whereas variable genes are located at the ends. The major virulence genes are namely ORFV homologous ovine gene encoding cytokine IL-10 (vIL-10), ORFV interferon resistance gene (OVIFNR), vascular endothelial growth factor (VEGF), the virus encoding chemokine binding protein (vCBP), ankyrin (ANK), dUTP pyrophosphatase (dUTPase), granulocytemacrophage colony stimulating factor (GMCSF) inhibiting factor (GIF), apoptosis inducing and inhibiting genes and ORFV121gene that inhibits the host NF- $\kappa \mathrm{B}$ pathway (Hosamani et al., 2009). The terminal genes are also supposed to be genus specific.

Orf virus possesses at least three classes of genes: early, intermediate early and late according to functional activation. In particular, a $20 \mathrm{kbp}$ DNA at the right terminus of the Orf virus genome contains genes not found in vaccinia virus, which may be involved in differences in the pathology of two viruses. The B2L (ORF 011) gene of the virus encodes a highly immunogenic major envelope protein of molecular weight $\sim 42$ kDa (Sullivan et al., 1994), which has been widely employed for the molecular detection of Orf virus infections by PCR and real time PCR along with the phylogenetic analysis of different strains of the virus (Inoshima et al., 2000).

\section{Host range}

The Orf virus affects sheep, goats, alpacas, camels, reindeer, big horn sheep, Sichuan takin, domestic Shetland sheep, deer, prong horn antelope, wapiti, Japanese serow, black buck, cats and seal squirrels (Oksanen and Norberg, 1994; Azwai et al., 1995; Robinson and Mercer, 1995; Thomas et al., 2003; Guo et al., 2004; Tryland et al., 2005; Fairley et al., 2008; Frandsen et al., 2011; Sharma et al., 2016). Humans are occasionally affected and dog can contract infection from consumption of Orf-contaminated carcasses (Hagis and Ginn, 2001).

\section{Epidemiology}

The Orf virus has worldwide distribution and more common in late summer, rain fall and winter on pasture and in feedlots. The virus is robust in a dry environment and can survive for months or even years, but its lifespan may 
become shorter in cold and wet conditions. The virus remains viable on the wool and hides for approximately one month after the lesions have healed, which leads to rejection of hide for international trade on zoonotic ground. The Orf virus is highly resistant to temperature and desiccation and has been recovered from dried crusts even after 12 years. The virus can survive at room temperature for more than 15 years and is also resistant to glycerol (Robinson and Balassu, 1981). Recently different outbreaks of the disease have been reported. Kumar et al., (2014) detected Orf virus in a goat flock in Central sheep breeding farm, Hisar, Haryana. Maan et al., (2014) reported from Rajasthan. Kumar et al., (2014) reported occurrence contagious ecthyma in Muzzafarnagri sheep flock in Central Institute for Research on Goat, Makhdoom, Mathura, U.P. Not only from India, from Turkey two clusters of Orf virus isolates have been investigated in two outbreaks in Goat flock (Sevik, 2017).

\section{Virus transmission}

The Orf virus usually gets transmitted through broken, scarified or otherwise abraded skin and replicates in epidermal cells. Predisposition to dried stemmy and spiny feed while grazing may produce breach in the soft tissues as lips, nostrils, mouth as well as forestomach. The Orf virus is usually transmitted through contact from infected to susceptible animals. However, transmission of the virus from clinically normal sheep to Orf naive sheep (Nettleton et al., 1996a) and following plunge dipping has also been reported (Sargison et al., 2007). Iatrogenic transmission of Orf virus may also occur during minor or major surgical intervention, hand contact, drenching and ear tagging (Allworth et al., 1987). Natural cross infection of Orf between sheep and goats can occur but experimental transmission of infection from one species to another may not be usually successful (de la ConchaBermejillo et al., 2003). Immuno compromised and persistently infected animals play an important role in the maintenance of Orf virus in nature (Ndikuwera et al., 1992, Yeruham et al., 2000). There is only partial protection following clinical disease or vaccination. Recurrent infections can occur in 1-3 months but are less severe and heal rapidly.

\section{Pathogenesis}

The infectious Orf virus paves its way through breach in skin and that is the primary predilection site to develop pathological lesions next to establishment. Through abrasions virus penetrates the skin of mucosa, replicates in the epidermal cells and leads to acanthosis, ballooning degeneration of spinose cells, hyperplasia of basal cells and edematous and granulomatous inflammation of dermal cells. Hence, producing the characteristic Orf lesions in a sequential manner as papules, vesicles, pustules, scabs and lastly resolution. The pustules develop within a few days but on rupture result into ulcer formation followed by thick overlaying crust or scab that is shed within 3-4 weeks leaving no scar (McKeever and Reid, 1987), which differs from poxviruses. Although, the pathogenesis of Orf seems to be simpler, it becomes too complex if bacterial super infection occurs. The most frequent invaders are Staphylococcus, $\quad \alpha$-hemolytic Streptococcus and Corynebacteria.

Sometimes the diagnosis of Orf is perplexed due to invasion by Dermatophillus congolensis, these may act together to produce large granulomatous masses extending 4 to $8 \mathrm{cms}$ proximally from the coronary band often referred to as "strawberry footrot"(NADIS, 2015). Fusobacterium necrophorum also spreads to viscera from buccal mucosal lesions. The visceral lesions 
extend down the gastrointestinal tract to produce tuberculous lesions leading to shedding of hooves. The same fungus is associated with venereal form of Orf as manifested with the development of ulcers on the vulva, prepuce and penis and accumulation of fluid in the scrotal sac of the ram. The Orf virus infecting the teats of lactating ewes may take climax to mastitis with or without invasion of Staphylococcus sp. (Thurman et al., 2015). Mastitis, occasionally gangrenous in nature, may follow the development of teat lesions. In human Orf lesion is co-mixtured with erythema multiforme and bullous pemphigoid-like eruptions (Alian et al., 2015). It is because of host immune response to Orf virus infection otherwise development of erythema multiforme following Orf infection is very rare (Ozturk et al., 2012, Shahmoradi et al., 2014). After clinical recovery, immunity of affected animals last for eight months to one year. However, the immune response to virus infection is predominantly accompanied by humoral immunity. The cell-mediated immune mechanism plays an important role in the process of recovery (McKeever et al., 1987).

\section{Virus virulence factors and evasion of host immunity}

There is development of short term immune memory in response to Orf virus infections so frequent repeated infections in sheep are commonly observed in spite of recovery from primary attack. This phenomenon may be because of many factors as the virus infects primarily the epidermal cells and undergoes limited replication before host anti-viral effector molecules reach the infection site. Secondly, the Orf virus elicits apoptosis in antigen presenting cells (APCs), epidermal and lymph cells besides suppressing the activation of T-cells via CD95/CD95L pathway (Kruse et al., 2001 and Garrido-
Farina et al., 2008). Apoptosis is also induced by viral dsRNA via triggering caspase cascade through caspase- 8 activation (Gil et al., 2000) but on its flip side, it prevents apoptosis of the infected cell via Bcl-2-like inhibitory effect on cytochrome $\mathrm{C}$ pathway, thereby exploiting the regenerating epidermal cells as predilection site. The Orf virus also exploits signal transduction pathways of the ubiquitin-proteasome system (UPS), circumvents the intracellular signal transduction and $\mathrm{CD} 8+\mathrm{T}$ activation, for shielding virus particles towards maturation and releasing outside ( $\mathrm{Yu}$ et al., 2013). Finally, the virus may be harbouring different mechanisms to interfere with the diverse components of protective host immune system as confirmed by discovery of several immunomodulating virulence genes (Alcami and Smith, 1995, 1997).Therefore, the difference in virulence of different strains of Orf viruses is due to mutation in these virulence factor genes (Martins et al., 2014).

The VEGF gene is very significant in proliferation of epithelial cells allowing the virus to infect the target cells (Lyttle et al., 1994). The Orf virus translates the 5 ANK proteins that degrade the host's anti-virus factors through the F-box-like domains via proteasome mechanism, thereby enhancing the virus replication and infection of different species (Sonnberg et al., 2008). The virus IL10 down regulates the $\mathrm{T}$-cell mediated immune response by altering the function of APCs. It is an anti-inflammatory cytokine and weakens the host immune system to clear up virus in infected epidermal cells (Imlach et al., 2002). The OVIFNR gene has interferon resistance function which frankly signifies the crucial role of interferon in host resistance to Orf virus infected animals (Haig and Mercer, 1998). The Orf virus synthesizes virus encoded cytokine binding protein (vCBP) discovered by Counago et al., (2010), that competitively inhibits binding site on the 
receptors of homogenous cytokines (Seet et al., 2003) and inhibits inflammation by preventing monocytes and DCs from transferring into the skin inflammatory lesions or peripheral lymph nodes. The ORFV121 encodes a novel NF- $\kappa \mathrm{B}$ inhibitor thus inhibits the phosphorylation and nuclear translocation of NF-kB-p65 thereby culminating the translation of the host immune-related genes. The GM-CSF inhibitory factor (GIF) with a WSXWS motif, encoded by the Orf virus
(McInnes et al., 2005) can specifically inhibit the biological activity of IL-2 (Th1 cytokines plays a critical role in the immune response against intracellular pathogens) and GM-CSF (pivotal in the recruitment and development of dendritic cells and macrophages for antigen presentation). These strengthen the Orf virus survival via evasion of specific and nonspecific immune responses (Deane et al., 2000).

Table.1 The key virulence factors encoded by Orf viruses, their functions and mechanism for immune evasion (reproduced from Zhang et al., 2014)

\begin{tabular}{|l|l|l|l|}
\hline S. No. & \multicolumn{1}{|c|}{ Protein } & \multicolumn{1}{c|}{ Host Targets } & \multicolumn{1}{c|}{ Major Function(s) } \\
\hline 1 & vIL-10 & DCs, Th1 & $\begin{array}{l}\text { inhibits the maturation of DCs, inhibits the proliferation } \\
\text { and transcription of a range of Th1 cell cytokines }\end{array}$ \\
\hline 2 & OVIFNR & dsRNA & $\begin{array}{l}\text { decreases the host IFNs response with PKR pathway } \\
\text { enhances the vascular permeability which is facilitated by } \\
\text { the viral replication and pustule formation }\end{array}$ \\
\hline 3 & VEGF & vascular endothelial & $\begin{array}{l}\text { inhibits the function of inflammation and DCs by } \\
\text { competitive binding cytokines }\end{array}$ \\
\hline 4 & CBP & DCs, cytokines & $\begin{array}{l}\text { degrade the host's anti-virus factors through the F-box-like } \\
\text { domains } \\
\text { cross-species infection }\end{array}$ \\
\hline 5 & ANK & Panthenol, proteasome & suppresses the function of IL-2 and GM-CSF \\
\hline 7 & GIF & Host dUTPase gene & $\begin{array}{l}\text { Inhibits the translation of the immune-related genes by } \\
\text { NF-kB pathway }\end{array}$ \\
\hline 8 & ORFV121 & NF-kB-p65 & induces or inhibits host cell apoptosis \\
\hline 9 & Other factors & CD95, cytochrome-C & \multicolumn{2}{|l}{} \\
\hline
\end{tabular}

\section{Host immune response to Orf virus infection}

The outcome of Orf virus infection depends on over-weigh of see-saw either by host immune responsive elements (humoral and/or cellular, innate and/or adaptive viz. immune response cells, antibodies and cytokines activity, etc.) or by viral virulence factors. Potent host immune response reduces the rate of Orf virus multiplication. Humoral immunity to the Orf virus is produced against five immunodominant antigens. Immune response is species specific as exemplified; the sheep polyclonal antibody raised against sheep Orf virus neutralizes more efficiently the respective sheep Orf virus than the goat Orf virus. This suggests that there may be some differences in neutralizing epitopes of Orf virus of ovine and caprine origin and hence the failure of the sheep Orf vaccine to protect goat kids (de la Concha-Bermejillo et al., 2003).

The host response to Orf virus infection is primarily characterized by initial infiltration of neutrophils followed by accumulation of dendritic cells, $\mathrm{CD} 4^{+} \mathrm{T}$ cells, $\mathrm{CD} 8^{+} \mathrm{T}$ cells and $\mathrm{B}$-cells around the virus infected epidermal cells. The rate and intensity of these cellular changes in the dermis parallels the presence of virus in the dermis and the clinical progression of the disease. $\mathrm{CD}^{+} \mathrm{T}$ cells are more numerous than $\mathrm{CD}^{+} \mathrm{T}$ cells at the lesion site although a proportion of both subsets are activated during infection. A 
peculiar characteristic of Orf virus lesion is the dense network of MHC Class II and dendritic cells adjacent to infected cells. The dendritic cells are crucial for antigen presentation, initiation and maintenance of immune response. In human skin, the histology of the Orf virus lesions is grossly similar to that of sheep. Apart from this, $\mathrm{CD}^{+}$ T-cells are important in host antiviral immunity for killing virus infected cells via MHC Class I pathway (Haig et al., 1999). Hence, there is a prompt humoral and CMIR to Orf virus infected host that involves $\mathrm{CD}^{+}$ cells, $\mathrm{CD}^{+}$cells, interferon and antibody.

\section{Laboratory diagnosis of Orf virus infection}

Commonly employed laboratory tests can be divided into different categories namely microscopic, serological and gene/ molecular tests and are described as under:

\section{Microscopic tests}

\section{Electron microscopy}

The electron microscopy (EM) is the quick method of diagnosis and differentiation of poxvirus infection in humans and animals. It can also differentiate Capripox from Parapoxvirus. The EM studies of Orf virus lesions in skin from musk ox, Sichuan takin and Shetland sheep revealed the presence of characteristic Parapoxvirus $200 \times 160 \mathrm{~nm}$ (approximately) virions as crisscross pattern against an electro dense background core (Guo et al., 2004).

\section{Histopathology}

The Orf virus affected skin tissues reveal vacuolization and hypertrophied keratinocytes from the external spinous layer of the epidermis, reticular degeneration (nuclear pyknosis and marked hydropic changes), marked epidermal proliferation, intra- epidermal and intra-dermal micro-abscesses and crust formation on the surface. Eosinophilic inclusion bodies are demonstrable in the cytoplasm of the infected cells but not always (Barraviera, 2005). It is also time and labour consuming as well as not very specific.

\section{Cell culture isolation}

Primary lamb testis, lamb kidney, fetal lamb dermis cells, fetal lamb muscle cells, ovine fetal turbinate cells, fetal bovine muscle cells and fetal bovine lung cells as well as cell line MDBK, MDOK, Vero cells are generally used for isolation of Orf virus (Inoshima et al., 1999, McInnes et al., 2001, Inoshima et al., 2002, Delhon et al., 2004). Following 2-3 blind passages, the CPE is visible in the form of mainly ballooning, rounding, degeneration and detachment of cells (Kruse and Weber, 2001, Vikoren et al., 2008). Furthermore, inoculation of the tissue culture positive isolates on chorioallantoic membrane (CAM) of embryonated chicken eggs results in thickening in the CAM in 5-7 days from inoculation as well as pock lesions particular to Poxviridae family.

\section{Serological tests}

\section{Serum neutralization test and complement} fixation test

The serum neutralization test (SNT) and complement fixation test (CFT) are usually used for sero-surveillance studies. A titre of $\geq 8$ and $\geq 20$ are considered positive in SNT and CFT, respectively (Zarnke et al., 1983). These tests are laborious and time consuming.

\section{Enzyme linked immunosorbent assay}

The enzyme linked immunosorbent assay (ELISA) has been used to screen serum samples of different species of animals 
employing purified antigens and peroxidase conjugated protein $A$ or $G$ or chimeric $A / G$ (Inoshima et al., 1999). It has been employed to screen serum samples of camel, lambs and humans for detection of antibodies to Orf virus (McKeever et al., 1987, Yirrell et al., 1994, Azwai et al., 1995).

\section{Molecular tests}

The most common Orf virus molecular markers having considerable importance in diagnosis and epidemiological studies with respect to identification of newly emerging strains are (i) a partial B2L gene (ORF011), (ii) VIR (ORF020), (iii) an envelope mature protein open reading frame 109 (ORF109), (iv) vIL10 (ORF127) and (v) GIF (ORF117) (Peralta et al., 2015). The various molecular biology based tests employed for the detection of Orf virus are as under:

\section{Polymerase Chain Reaction}

A polymerase chain reaction (PCR) based on B2L or VIR gene has been employed to diagnose the Parapoxvirus infections (Inoshima et al., 2000, Kottaridi et al., 2006). A semi-nested PCR based on the major enveloped protein B2L gene has been reported to detect low copy number of virus particles from clinical samples. The efficacy of PCR was comparable (85-87\%) to the cell culture/ neutralization methods. A duplex PCR assayusing A29 gene (413 bp) and H3L gene (708 bp) has considerable potential as a diagnostic approach for detection and differentiation of CPV and ORFV (Zheng et al., 2007).

\section{Real time PCR}

The TaqMan real time PCR has been developed to detect and quantify ORFV DNA in infected cell culture and clinical samples based on B2L gene. Moreover it is able to differentiate Orf virus from PCPV, BPSV and seal parapox virus (Gallina et al., 2006, Nitsche et al., 2006, Venkatesan et al., 2012). Other test based on primers and probes usage to amplify an $87 \mathrm{bp}$ fragment DNA sequence of ORFV024 gene encoding an NF- $\kappa \mathrm{B}$ inhibitor of Orf virus. It was highly specific and sensitive for ORFV DNA and no crossreactions were detected with any other poxviruses; the sensitivity was $5 \mathrm{fg}$ or 15 copies of ORFV genomic DNA (Du et al., 2013).

\section{Restricted Fragment Length Polymorphism (RFLP)}

Restriction enzymes (RE) digestion pattern of genomic DNA are characteristic and hence exploited for genome typing. A number of RE enzymes like EcoRI, BamHI and HindIII have been used for molecular characterization of different strains of parapoxviruses. Viral DNA digested with $K p n I$ and DraI was found better for genome typing and determining the virus heterogenicity (Rafii and Burger, 1985). However, it is less useful in species differentiation.

\section{Isothermal amplification assay}

The loop-mediated isothermal amplification (LAMP) assay is specific, has no crossreactivity with Sheeppox virus, Goatpox virus, Avian molluscum roup virus or Vesicular stomatitis virus.

Additionally, the sensitivity of the LAMP method has been found to be similar to that of real-time PCR and has greater sensitivity than a conventional PCR assay. LAMP assay developed using viral DNA polymerase gene (Song et al., 2013). Yang et al., (2016) developed a novel "point of care" molecular amplification assay for quick on spot visual detection of ORFV based on isothermal recombinase polymerase amplification (RPA) 
technology in combination with a simpler lateral flow immunoassay strip (ORFV RPALFD assay).

\section{Sequencing and phylogenetic analysis}

Recently developed sequencing and bioinformatics tools for data analysis have helped in tracing out finer details of virus evolution and spread. Klein and Tryland (2005) carried out partial sequence analysis of B2L and vIL-10. Hosamani et al., (2006) performed sequence analysis of major envelope gene (B2L) of four Indian Orf virus isolates originating two each from sheep and goats. Hosamani et al., (2007) characterized an Indian Orf virus isolate from goats by sequencing of full-length GM-CSF and interleukin-2 inhibitory factor (GIF) gene. Vankatesan et al., (2011) carried out sequence analysis of B2L of an Indian isolate of $\mathrm{Orf}$ virus from sheep (Muk TS/2009 and Muk/2000). Kumar (2014) confirmed the Orf virus identity by amplification and sequence analysis of the major envelope glycoprotein (B2L) gene and named ORFV/sheep/ India/2012/CIRG. On phylogenetic analysis of B2L protein gene, it clustered with the Orf virus strains from China suggesting distinct Orf virus strains circulating in India. Dalal et al., (2015) also characterized the virus isolates from Haryana by B2L and IL2 genes based phylogenetic studies. Zhang et al., (2016) phylogenetically analysed three Orf virus strains from different districts of Shandong Province, East china.

\section{Vaccination}

Although, a variety of vaccines are available against Contagious ecthyma, live attenuated vaccines are always considered superior and taken into practice where Orf infections are endemic. As per classical Jenner approach, shed or intact scab material triturated in saline with additive antibiotic penicillin/ streptomycin acts an autologous vaccine which can be given by scarification in the inner thigh or other suitable area but not on face or legs as in variolation. Mild inflammatory swelling and scabbing occur at scarification site signify the immunological protection. If a herd is immunized $>80 \%$, there may not be budding of fresh cases for a few years but when unvaccinated newborn animals over number increase, the disease may recur (Bath et al., 2005). Live attenuated tissue culture vaccine has been found to be effective in reducing the disease severity (Nettleton et al., 1996b). Furthermore, main disadvantage of this vaccine is that it can disseminate the vaccine virus strain capable of causing the disease and unable to confer solid immunity to re-infection (Buddle et al., 1984). A live attenuated vaccine based on primary chicken embryo fibroblast tissue cultures has been prepared and freeze-dried following the quality control procedures as per the European Pharmacopoeia (Mercante et al., 2008).

As a new approach DNA vaccines have been experimented in mice model to combat spread of Orf (a) bacterial plasmid as vector viz., plasmid expressing ORF011 and ORF059 (pcDNA3.1-ORFV011/ORFV059) as chimeric-proteins demonstrated significant improvement in the Orf virus-specific antibody titres (serum IgG1/IgG2a), the proliferation of lymphocytes and ORFVspecific cytokines (IL-2, IL-4, IL-6, IFN- $\gamma$, and TNF- $\alpha$ ) Zhao et al., 2011. (b) Virus as vector recombinant Goatpox virus expressing Orf virus F1L gene has been tested as vaccine candidate against $\mathrm{CE}$ virus but found to be sensitive to acids, alkalis, organic solvents and ultraviolet (Zang et al., 2014). Bora et al., (2015) studied effect of different stabilizers as LS, LHT and TAA and diluents NSS, DW, $1 \mathrm{M} \mathrm{MgSO}_{4}$ and PBS on the stability of a novel strain of live attenuated Orf vaccine (ORFV MUK59/05) and suggested that LS at 
25 and $45^{\circ} \mathrm{C}$ and LHT at $37^{\circ} \mathrm{C}$ are choice of stabilizers and $0.85 \%$ NSS is choice of diluent for the vaccine at all temperatures studied.

This review highlights the importance of "Orf", signifying the disease continuation in present time in livestock animals. Different advancements in the field of diagnostics have now reached to molecular level with pen side detection of diseases. However, different patho-physiological factors of Orf virus virulence and host immune system are required to be studied and analysed together in more details to achieve better control and preventive measures.

\section{References}

Alcami, A. and Smith, G.L. 1995. Cytokine receptors encoded by poxviruses: a lesion in cytokine biology. Immunol. Today16: 474-479.

Alcami, A. and Smith, G.L. 1997. Soluble interferon- $\gamma$ receptors encoded by pox viruses. Comp. Immunol. Microbiol. Infect. Dis. 19: 305- 319.

Alian, S. Ahangarkani, F. and Arabsheybani, Sara. 2015. A Case of Orf Disease Complicated with Erythema Multiforme and Bullous Pemphigoid-Like Eruptions. Case Reports in Infectious Diseases vol. 2015 Article ID 105484, 4 pages http://dx.doi.org/10.1155/2015/ 105484. Hindawi Publishing Corporation.

Allworth, M.B., Hughes, K.L. and Studdert, M.J. 1987. Contagious pustular dermatitis (orf) of sheep affecting ear following ear tagging. Aust. Vet. J.64: 61-62.

Azwai, S.M., Carter, S.D. and Woldehiwet, Z. 1995. Immune responses of the camel (Camelus dromedurius) to contagious ecthyma (Orf) virus infection. Vet. Microbiol.47: 119-131.

Barraviera, S.R.C.S. 2005. Diseases caused by poxvirus-Orf and milker's nodulesa review. J. Venom. Anim. Toxins Incl. Trop. Dis.11: 102- 108.

Bath, G.F., van Wyk, J.A. and Pettey, K.P. 2005. Control measures for some important and unusual goat diseases in southern Africa. Small Rumin. Res.60: 127-140.

Bora, M.D.P., Bhanuprakash, V., Venkatesan, G., et al., 2015. Effect of stabilization and reconstitution on the stability of Novel strain live attenuated Orf vaccine (ORFV MUK59/05). Asian J. Anim. Vet. Adv. 10(8): 365-375.

Buchen Osmond, C. (2003). ICTV db Index of Viruses: Catalogue of Virus Taxonomy and Nomenclature approved by the International Committee of Taxonomy of Viruses, Available from http://www.ncbi.nlm.nih.gov/ICTVdb/I ctv/fr-Index.htm.

Buddle, B.M., Dellers, R.W. and Schurig, G.G. 1984. Contagious ecthyma virus vaccination failures. Am. J. Vet. Res. 4: 263-266.

Caravaglio, J.V. and Khachemoune, A. 2017. Orf Virus Infection in Humans: A review with a focus on advances in diagnosis and treatment. J. Drugs Dermatol. 16(7): 684-689.

Centers for Disease Control and Prevention (CDC). 2012. Human Orf Virus Infection from Household ExposuresUnited States, 2009-2011. MMWR Morbidity and Mortality Weekly Report, 61, 245-248.

Dalal, A., Kumar, A., Maan, S., Batra, K., Sunayana and Kakker, N.K. 2015. Molecular characterization of coantagious ecthyma (ORF) virus from small ruminants. Indian J. Comp. Microbiol. Immunol. Infect. Dis. ISSN0974-0417, 36(2).

De la Concha-Bermejillo, A. 1995. Poxviral diseases. In: Health Hazards in Veterinary Practice. 
De la Concha-Bermejillo, A., Guo, J., Zhang, Z. and Waldron, D. 2003. Severe persistent orf in young goats. J. Vet. Diagn. Invest.15: 423-431.

Dean, D., McInnes, C.J., Percival, A., Wood, A., Thomson, J., Lear, A., Gilroy, J., Fleming, S., Mercer, A. and Haig, D. 2000. Orf virus encodes a novel secreted protein inhibitor of granulocyte macrophage colony-stimulating factor and interleukin-2. J. Virol.,74: 13131320.Counago RM, Fleming, S.B., Mercer, A.A. and Krause, K.L. 2010. Crystallization and preliminary X-ray analysis of the chemokine-binding protein from orf virus (Poxviridae). Acta. Crystallo. gr. Sect. F., Struct. Biolcryst. commun. 66: 819-823.

Delhon, G., Tulman, E.R., Afonso, C.L., Lu, Z., de la Concha-Bermejillo, A., Lehmkuhl, H.D., Piccone, M.E., Kutish, G.F. and Rock, D.L. 2004. Genomes of the parapoxviruses ORF virus and bovine papular stomatitis virus. J. Virol.78: 168-177.

Du, H., Li, W., Hao, W., Liao, X., Li, M. and Luo, S. 2013. Taqman real-time PCR assay based on ORFV024 gene for rapid detection of orf infection. Toxicol Mech Methods. DOI: $10.3109 / 15376516$. 2012.753968

Fairley, R.A., Whelan, E.M., Pesavento, P.A. and Mercer, A.A. 2008. Recurrent localised cutaneous parapoxvirus infection in three cats. N. Zeal. Vet. J. 56: 196-201.

Farris, R., Mahlow, J., Newman, E., Nix, B. (Eds.), American Veterinary Medical Association, Schaumburg.

Fleming, S.B., Blok, J., Fracer, K.M., Mercer, A.A. and Robinson, A.J. 1993. Conservation of gene structure and arrangement between vaccinia virus and orf virus. Virology195: 175-184.

Frandsen, J., Enslow, M. and Bowen, A.R. 2011. Orf parapoxvirus Infection from a
Cat Scratch. Dermatology Online Journal, 17: 9.

Frandsen, J., Enslow, M. and Bowen, A.R. 2011. Orf parapoxvirus infection from a cat scratch. Dermatol. Online J. 17, e9.

Garrido-Farina, G.I., Cornejo-Cortes, M.A., Martinez-Rodriguez, A., ReyesEsparza, J., Alba-Hurtado, F. and Tortora-Perez, J. 2008. A study of the process of apoptosis in animals infected with the contagious ecthyma virus. Veterinary microbiology. 129: 28-39.

Gil, J. and Esteban, M. 2000. Induction of apoptosis by the dsRNA-dependent protein kinase (PKR): mechanism of action. See comment in PubMed Commons below Apoptosis. 5: 107-114. Gumbrell, R.C. and McGregor, D.A. 1997. Outbreak of severe fatal orf in lambs. Vet. Rec.141: 150-151.

Guo, J., Rasmussen, J., Wunschmannd, A. and de la Concha-Bermejillo, A. 2004. Genetic characterization of orf viruses isolated from various ruminant species of a zoo. Vet. Microbiol. 99: 81-92.

Hagis, A.M. and Ginn, P.E. 2001. Integumentary system. In: Thomson's Special Veterinary Pathology. McGravin, M.D., Carlton, W.W., Zachary, J.F. (Eds.), Mosby, Inc., London.

Haig, D.M. and McInnes, C.J. 2002. Immunity and counter immunity during infection with the parapoxvirus orf virus. Virus Res.88: 3-16.

Haig, D.M. and Mercer, A.A. 1998. Ovine diseases: Orf. Vet. Res.29: 311-326.

Haig, D.M., Thomson, J., McInnes, C.J., McCaughan, C., Imlach, W., Mercer, A., Fleming, S. 2002. Orf virus immuno-modulation and the host immune response. Vet. Immunol. Immunopathol. 87: 395-399.

Hoare, E.W. 1913. Contagious pustular dermatitis of sheep. In: "A system of veterinary medicine". E.W Hoare, 
Bailliere Tindall and Cox (Eds), London, pp. 300-309.

Hosamani, M., Bhanuprakash, V., Scagliarini, A. and Singh, R.K. 2006. Comparative sequence analysis of major envelope protein gene (B2L) of Indian orf viruses isolated from sheep and goats. Vet. Microbiol., 116: 317-324.

Hosamani, M., Scagliarini, A., Bhanuprakash, V., McInnes, C.J. and Singh, R.K. 2009. Orf: an update on current research and future perspectives. See comment in PubMed Commons below Expert Rev Anti Infect Ther. 7: 879-893.

Hosamani, M., Yadav, S., Kallesh, D.J., Mondal, B., Bhanuprakash, V., and Singh, R. K. 2007. Isolation and characterization of an Indian ORF virus from goats. Journal Zoonoses and Public Health, 54: 204-208.

Housawi, F.M.T., Roberts, G.M., Gilray, J.A., Pow, I., Reid, H.W., Nettleton, P.F., Sumption, K.J., Himba, M.H. and Mercer, A.A. 1998. The reactivity of monoclonal antibody against orf virus with other parapoxviruses and the identification of a $39 \quad \mathrm{kDa}$ immunodominant protein. Arch. Virol.143: 2289-2303.

Imlach, W., McCaughan, C.A., Mercer, A.A., Haig, D. and Fleming, S.B. 2002 Orf virus- encoded interleukin-10 stimulates the proliferation of murine mast cells and inhibits cytokine synthesis in murine peritoneal macrophages. See comment in PubMed Commons below J Gen Virol. 83: 1049-1058.

Inoshima, Y., Murakami, k., Wu, D. and Sentsui, H. 2002. Characterization of parapoxviruses circulating among wild Japanese serows (Capricornis crispus). Microbiol. Immunol.46: 583-587.

Inoshima, Y., Murakami, K., Yokoyama, T. and Sentsui, H. 2000. Genetic heterogeneity among parapoxviruses isolated from sheep, cattle and Japanese serows (Capricornis crispus). J. Gen. Virol.82: 1215-1220.

Inoshima, Y., Shimizu, S., Minamoto, N., Hirai, K. and Sentsui, H. 1999. Use of protein $A G$ in an enzyme linked immunosorbent assay for screening for antibodies against parapoxvirus in wild animals in Japan. Diagn. Lab. Immunol.6: 388-391.

Key, S.J., Catania, J., Mustafa, S.F., Logan, R., Kalavala, M., Hodder, S.C. and Patton, D.W. 2007. Unusual presentation of human giant orf (Ecthyma contagiosum). J. Craniofac. Surg.18: 1076-1078.

Khaled, A., Robbana, F., Hammami, H., Kharfi, M., El Fekih, N., Fazaa, B. and Kamoun, M.R. (2009) Orf of the Hand. Tunis Medicine, 87, 352-353

Klein, J. and Tryland, M. (2005). Characterization of parapoxviruses isolated from Norwegian semi domesticated reindeer (Rangifera tarandus tarandus). Virol. J. Vol. 2:79:1-10.

Kottaridi, C., Nomikou, K., Lelli, R., Markoulatos, P. and Mangana, O. 2006. Laboratory diagnosis of contagious ecthyma: comparison of different PCR protocols with virus isolation in cell culture. J. Virol. Methods.134: 119124.

Kruse, N. and Weber, O. 2001. Selective induction of apoptosis in antigenpresenting cells in mice by Parapoxvirus ovis. See comment in PubMed Commons below J Virol. 75: 4699-4704.

Kumar, A., Maan, S., Gosh, A., Batra, K and Sharma, H. 2014. Identification and characterization of Orf virus from goats. Indian J. Comp. Microbiol. Infect. Dis.34(2): galley proof.

Kumar, N., Wadhwa, A., Chaubey, K. K., Singh, S. V., Gupta, S., Sharma, S., Sharma, D.K., Singh M.K. and Mishra, 
A.K. 2014. Isolation and phylogenetic analysis of an orf virus from sheep in Makhdoom, India. Virus Genes48: 312319.

Kumar, T., Sindhu, N., Kumar, A., Charaya, G., Kumar, A., Maan, S. and Mahajan, N.K. 2016. An outbreak of contagious ecthyma with rare tongue lesions in a goat flock in Haryana. Harayana Veterinarian.55(2):185-187.

Lyttle, D.J., Fraser, K.M., Fleming, S.B., Mercer, A.A. and Robinson, A. 1994. Homology of vascular endothelial growth factor are encoded by the poxvirus orf virus. J. Virol.68: 84-92.

Maan, S., Kumar, A., Batra, K., Singh, M., Nanda, T., Ghosh, A. and Maan, N.S. 2014. Isolation and molecular characterization of contagious pustular dermatitis virus from Rajasthan, India. Virus Diseases. DOI 10.1007/s13337014-0205-0

Martins, M., Cargnelutti, J.F., Weiblen, R. and Eduardo F. Flores. 2014. Pathogenesis in lambs and sequence analysis of putative virulence genes of Brazilian Orf virus isolates. Veterinary Microbiology. 174:69-77.

Matthews, R.E.F. 1982. Classification and nomenclature of viruses. 4th report Committee on taxonomy of viruses. Intervirol.17: 1-199.

McInnes, C.J., Deane, D., Haig, D., Percival, A., Thomson, J. and Wood, A.R. 2005. Glycosylation, disulfide bond formation, and the presence of a WSXWS-like motif in the orf virus GIF protein are critical for maintaining the integrity of Binding to ovine granulocyte-macrophage colonystimulating factor and interleukin-2. J. of viro. 79: 11205-11213.

McKeever, D.J. and Reid, H.W. 1987. The response of the supramammary lymph node of sheep to secondary infection with orf virus. Vet. Microbiol.14: 3-13.
McKeever, D.J., Jenkinson, D.M., Hutchison, G. and Reid, H.W. 1988. Studies on the pathogenesis of orf virus infection in sheep. J. Comp. Pathol. 99: 317-328.

McKeever, D.J., Reid, H.W., Inglis, N.F. and Herring, A.J. 1987. A qualitative and quantitative assessment of humoral antibody response of sheep to orf virus infection. Vet. Microbiol.15: 229-241.

Mercante, M.T., Lelli, R., Ronchi, G.F., Fini, A. 2008. Production and efficacy of an attenuated live vaccine against contagious ovine ecthyma. Vet. Ital.44: 537-542.

Mercer, A.A., Ueda, N., Friederichs, S.M., Hofmann, K., Fraser, K.M., Bateman, T. and Fleming, S.B. 2006. Comparative analysis of genome sequences of three isolates of Orf virus reveals unexpected sequence variation. Virus Research 116: 146-158.

Mercer, A.A., Yirrell, D.L., Reid, H.W. and Robinson, A.J. 1995. Lack of cross protection between vaccinia virus and orf virus in hysterectomy procured, barrier maintained lambs. Vet. Microbiol.41: 373- 382.

Mercer, A.A., Yirrell, D.L., Whelan, E.M., Nettleton, P.F., Pow, I., Gilray, J.A., Reid, H.W. and Robinson, A.J. 1998. A novel strategy for determining protective antigens of the parapoxvirus, orf virus. Virology 229: 193-200.

Mondal, B., Bera, A.K., Hosamani, M., Tembhurne, P.A. and Bandyopadhyay, S.K. (2006). Detection of orf virus from an outbreak in goats and its genetic relation with other parapoxviruses. Vet. Res. Commun.30: 531-539.

NADIS, National Animal Disease Information Service (2015) Contagious postular dermatitis (orf). Leaflet [online]. www.nadis.org.uk/bulletins/ contagious-pustular-dermatitis (orf). aspx ?altTemplate $=$ PDF. Accessed May 21, 2013. 
Ndikuwera, J., Odiawo, G.O., Usenik, E.A., Koch, N.D., Ogaa, J.S. and Kuiper, R. 1992. Chronic contagious ecthyma and caseous lymphadenitis in two Boer goats. Vet. Rec.131: 584-585.

Nettleton, P.F., Brebner, J., Paw, J., Gilray, J.A., Bell, G.D. and Reid, H.W. 1996b. Tissue culture propagated orf virus vaccine protects lambs from orf virus challenge. Vet. Rec.138: 184-185.

Nettleton, P.F., Gilray, J.A., Yirrell, D.L., Scott, G.R. and Reid, H.W. 1996a. Natural transmission of orf virus from clinically normal ewes to orf-naive sheep. Vet. Rec.139: 364-366.

Nitsche, A., Buttner, M., Wilhelm, S., Pauli, G. and Meyer, H. 2006. Real-time PCR: detection of parapoxvirus DNA. Clin. Chem.52: 316-319.

Oksanen, A. and Norberg, H. 1994. Smittsom munnskurv. Reindriftsnytt 3-4: 13-17.

Ozturk, P., Sayar, H., Karakas, T., and Akman, Y. 2012. Erythema multiforme as a result of Orf disease. Acta Dermato venerologica Alpina, Pannonica et Adriatica, 21(2):45-46.

Peralta, A., Robles, C., Martínez, A., Alvarez, L., Valera, A., Calamante, G. and König, G.A. 2015. Identification and molecular characterization of Orf virus in Argentina. Virus Genes. 50(3): 3818. doi: 10.1007/s11262-015-1189-6.

Peterkin, G.A. 1937. The occurrence in humans of contagious pustular dermatitis of sheep ("orf"). Br. J. Dermatol. Syphilis. 49:492-497.

Rafii, F. and Burger, D. 1985. Comparison of contagious ecthyma virus genomes by restriction endonucleases. Arch. Virol.84: 283-289.

Robinson, A.J. and Balassu, T.C. 1981. Contagious pustular dermatitis (orf). Vet. Bull.51: 771-782.

Robinson, A.J. and Mercer, A.A. 1995. Parapoxvirus of red deer: evidence for its inclusion as a new member in the genus Parapoxvirus. Virology208: 812815.

Rørdam O.M., ØysteinGrimstad, Spigset, O. and Ryggen K. 2013. Giant Orf with Prolonged Recovery in a Patient with Psoriatic Arthritis Treated with Etanercept. Acta Derm Venereol. 93

Sargison, N.D., Scott, P.R. and Rhind, S.M. 2007. Unusual outbreak of orf affecting the body of sheep associated with plunge dipping. Vet. Rec.160: 372-373.

Seet, B.T., McCaughan, C.A., Handel, T.M., Mercer, A., Brunetti, C., McFadden, G., et al., 2003 Analysis of an orf virus chemokine-binding protein: Shifting ligand specificities among a family of poxvirus viroceptors. ProcNatlAcadSci USA. 100: 15137-15142.

Sevik, M. 2017. Association of two clusters of Orf virus isolates in outbreaks of infection in goat in the Central Anatolian region of Turkey. Virus Disease. 28(3):345-348.

Shahmoradi, Z., Abtahi-Naeini, B., Pourazizi, M., and Meidani M. 2014. "Orf disease following 'eidul-adha': a rare cause of erythema multiforme," International Journal of Preventive Medicine, 5(7):912-914.

Sharma, A.K., Venkatesan, G., Mathesh, K., Ram, H., Ramakrishnan, M.A. and Pandey, A.B. 2016. Occurrence and identification of contagious ecthyma in blackbuck.. Virus disease. 27(2):198202.

Sonnberg, S., Seet, B.T., Pawson, T., Fleming, S.B. and Mercer, A.A. 2008. Poxvirus ankyrin repeat proteins are a unique class of F-box proteins that associate with cellular SCF1 ubiquitin ligase complexes. ProcNatlAcadSci USA. 105: 10955-10960.

Thomas, K., Tompkins, D.M., Sainsbury, A.W., Wood, A.R., Dalziel, R., Nettleton, P.F. and McInnes, C.J. 2003. A novel poxvirus lethal to red squirrels 
(Sciurus vulgaris). J. Gen. Virol. 84: 3337-3341.

Thurman RJ, Fitch RW (2015). Images in clinical medicine. Contagious ecthyma. N. Engl. J. Med. 372(8):e12. http:// dx.doi.org/10.1056/NEJMicm1304779

Tryland, M., Klein, J., Nordoy, E.S. and Blix, A.S. 2005. Isolation and partial characterization of a parapoxvirus isolated from a skin lesion of aWeddell seal. Virus Res.108: 83-87.

Venkatesan, G., Balamurugan, V., Bora, D. P., Yogisharadhya, R., Prabhu, M. and Bhanuprakash, V. 2011. Sequence and phylogenetic analyses of an Indian isolate of orf virus from sheep. Vet Ital.47: 323-32.

Venkatesan, G., Bhanuprakash, V., Balamurugan, V., Bora, D. P., Prabhu, M., Yogisharadhya, R. and Pandey A. B. 2012. Rapid detection and quantification of Orf virus from infected scab materials of sheep and goats. Acta Virol.56: 81-3.

Vikoren, T., Lillehaug, A., Akerstedt, J., Bretten, T., Haugum, M. and Tryland, M. 2008. A severe outbreak of contagious ecthyma (orf) in a freeranging musk ox (Ovibos moschatus) population in Norway. Vet. Microbiol. 127: 10-20.

Walley, T. 1890. Contagious dermatitis: "Orf" in sheep. J. Comp. Pathol. 3: 357360.

Yang, Y., Qin, X., Wang, G., Jin, J., Shang, Y. and Zhang, Z. 2016. Development of an isothermoal amplification-based assay for rapid visual detection of an Orf virus. Virology Journal 13:46

Yeruham, I., Perl, S. and Abraham, A. 2000. Orf infection in four sheep flocks. Vet. J. 160: 74-76.

Yirrell, D.L., Vestey, J.P. and Norval, M. 1994. Immune responses of patients to orf virus infection. Br. J. Dermatol.130(4), 438-443

Yu, Y.Z., Tong, C.Y., Song, B.F., An, H.B., Yu, L.Y., Yu, L., Cui, Y.D. 2013. Molecular mechanism of ORFV intervention strategies based on the UPS of host cell: a review. Chinese J. Virol. 29(6):662-666.

Zarnke, R.L., Dieterich, R.A., Neiland, K.A. and Ranglack, G. 1983. Serological and experimental investigations of contagious ecthyma in Alaska. J. Wildl. Dis. 19: 170-173.

Zhang, K., Liu, Y., Kong, H., Shang, Y. and Liu, X. 2014. Comparison and phylogenetic Analysis based on the B2L gene of Orf virus from goats and sheep in China during 2009-2011. Archives of Virology. 159(6): 1475-1479.

Zhang, K., Xiao, Y., Yu, M., et al., 2016 Phylogenetic analysis three orf virus strains from different districts of Shandong Province, East china. J. Vet. Med. Sci. 77(12):1639-1645.

Zheng, M., Liu, Q., Jin, N., Guo, J., Huang, X., Li, H., Zhu, W. and Xiong, Y. 2007. Duplex PCR assay for simultaneous detection and differentiation of Capripoxvirus and Orf virus. Mol. Cell. Prob. 21: 276-281.

\section{How to cite this article:}

Anita Dalal, Vinay Kumar, Deepika Chaudhary, Nitish Bansal, Aman Kumar, Naresh Kakker and Sushila Maan. 2017. Past and Present Overview of "Orf". Int.J.Curr.Microbiol.App.Sci. 6(12): 2159-2173. doi: https://doi.org/10.20546/ijcmas.2017.612.248 